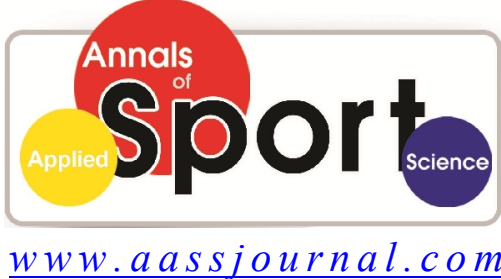

ISSN (Online): 2322 - 4479

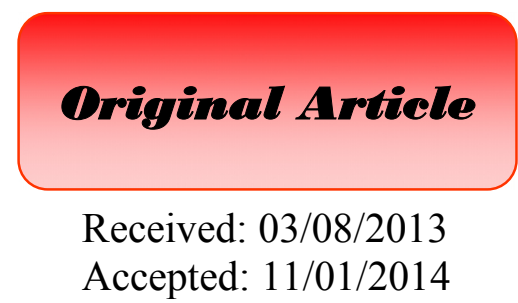

Accepted: 11/01/2014

\title{
Factor Analysis of Teenage Athletes' Goal Orientations and Sports Participation Motives in Leisure Time
}

\section{${ }^{1}$ Noshin Benar ${ }^{*},{ }^{2}$ Mohsen Loghmani}

1. Department of Sport Management, Faculty of physical education and sport sciences, Guilan University, Rasht, Iran.

2. Department of physical education and sport sciences, Faculty of humanities, Bu-Ali Sina University, Hamedan, Iran.

\section{ABSTRACT}

The aim of the present study was to identify the most important goal orientations and sport participation motives among teenage athletes in leisure time. In addition, these variables were prioritized and associations between all constructs have been studied. For this purpose, 376 Iranian teenage athletes were singled out by cluster-random sampling, and responded to Task and Ego Orientation Sport Questionnaire (T.E.O.S.Q), and Participation Motivation Questionnaire (PMQ). The results of Confirmatory Factor Analysis (CFA) showed fit model indexes for twosome dimensions of sport goals, and five motives of sport participation (RMSEA $\leq .06 ; \chi^{2} / \mathrm{df} \leq 3$; Goodness Indexes $\geq .90)$. Based on CFA and loadings, goals of task-orientation $(r=.93)$ and egoorientation $(\mathrm{r}=.43)$ were identified for sport goals, and motives of energy release $(\mathrm{r}=.94)$, status $(\mathrm{r}$ $=.76)$, fitness $(\mathrm{r}=.48)$, team atmosphere $(\mathrm{r}=.46)$, and skill development $(\mathrm{r}=.26)$ obtained for teenagers' sport participation, respectively. In general, the findings of the present study provided the adequate understanding for sport managers, coaches, physical educators and their parents by how sport motivation of teenagers, via satisfying teenager's motives specially motives of energy release and status, provided their satisfaction and gratification during long life.

Key Words: Confirmatory Factor Analysis, Growth Roods Sports, Energy Release, Status, Task Orientation. 


\section{INTRODUCTION}

Leisure describes a state in which people free themselves from daily obligations, anxieties, and pressures $(1,2)$. According to Barnett (2006), leisure is a "reflection and extension of our uniquely individualistic personality" and a mean to resist laziness (3). Thus, people who participate in leisure activities for intrinsic rewards pursue challenges and feel self-determined, competent, and deeply involved (4). Intrinsic motivation and exercising for leisure relate to an increase in leisure activities during physical activity (3). Opportunities for intrinsic rewards exist in many leisure activities (5). High intrinsic motivation in leisure pursuits corresponds with increased enjoyment and time spent participating in activity and influences many aspects of human behavior (6). Therefore, continued motivation depends on the promotion of mastery and competence (3). Conducive activities for leisure, such as sedentary and large-muscle activities, provide a satisfying experience (1). While stress depends on personal interpretation, stress relief depends on self-determination, which results in positive or negative experiences with leisure (7).

However, Biddle (1998) has founded motives of fun, social aspects, and skill development (8), in other researches of sport participation motivation fields, findings showed that six main motives such as skill development, status, team atmosphere, energy release, affiliation, and fitness existed in teenager's sport participation motivation $(9,10)$.

Researchers' interest in sport participation motivation led to conduct lateral studies in this field. For example, Benar and Loghmani (2012) quoting from Fauzee et al. (2009) explored motives of eleven football players of university, and indicated that coaches and motivational words are the highest external factors that motivate them to participate in sports. In their study, external factors of motives included friends, rewards, role model, and parents. They believed that the psychological factors of leaderships and verbal persuasion do play an important role to motivate athletes (11). In similar, Cecchini et al. (2002) demonstrated that motivational differences were found according to sex, age, type of population and intensity of motivation for sport (12). In other contexts, Rees and Sabia (2010) examined effect of sports participation on several measures of academic performance. Their results provided only limited evidence that sports participation leads to enhanced academic performance (13). In similar studies, sport participation motivation predicted from meta-motivational dominances and orientations (14). Slutzky and Simpkins (2009) studied the mediating role of sport self-concept in link between children's sport participation and selfesteem. Findings of their research indicated that children who spent more time in team sports, but not time in individual sports, reported higher sports self-concept, which, in turn, was associated with higher selfesteem than their peers (15).

Achievement goal theory describes the effect of task and ego orientations on the motivation process and the influence of perceived competency and ability on behavior (16-18). Studies focus on the "energization and direction of competencerelevant behavior" (19), and this theory considers a person's idea of success. The imbalance of sport ability and perceived competence influence a person's adoption of an achievement goal (17). Boyd et al. (2002) also addresses competence and the avoidance of incompetence as reasons for achievement behavior. They emphasize that a person understands competence and definition of success influences his or her achievement goal preferences (19). Hence, 
task-orientation and ego-orientation have been accepted among researchers (20). Task-oriented individuals emphasize on fitness promotion and technique performance skillfully, while ego-oriented individuals emphasize on competition, status and confirming their abilities to their peers.

Researchers have been conducted in the field of achievement goal theory. For instance, Benar and Loghmani (2012a) examined relations of goal orientations and sports commitment among athletes. They indicated that there were clearly and significantly associations between both variables of goal orientations and sport commitment. The most important of results illustrated that there is negative and significant correlations between task orientation and sports commitment. Also, findings of their research showed that team and open-skilled sports athletes had sports commitment and ego-orientation more than individuals and closed-skilled sports athletes. As well as, female's athletes had sports enjoyment and social support more than male athletes (11). In similar study, the same authors (Benar and Loghmani, 2012b) showed that those who participated in individual sports had more motivation for status than team sports athletes and they were more ego-orientated. Also it was found that more highly educated mothers came to induce internal motivation in youth athletes, whereas more highly educated fathers came to induce both internal and external motivation to them (21).

\section{MATERIALS AND METHODS}

Subjects. In this study 376 Iranian youth athletes (boy $=214$, girl $=162$ ) were studied. Data was obtained about the youths who participated in sport activities in their leisure time such as basketball $(\mathrm{n}=132)$, football $(n=73)$, volleyball $(n=82)$ and combat $(n=$ 89) sports. The age of our statistical universe is $12-16$ years old.
Instruments. Participation Motivation Questionnaire (PMQ) of Gill, Gross \& Huddleston (1983) was used to gather data about the sports participation motivation (20). This questionnaire has 30 questions that assess the possible reasons to participate in sports programs. In this questionnaire, 5point Likert scale was used from 1 (that is not important) to 5 (that is very important). Researchers introduced 6 important motivations including status, energy release, team atmosphere, skill development, affiliation and fitness. In this study, we saw accepted reliability for questionnaire by Cronbach's alpha coefficient $(r=.85)$, such as our recent study (21).

To gather the goal-orientation, participants of the present study answered the Task and Ego-Orientation in Sport Questionnaire (TEOSQ) of Duda and Nicholls (1992) (22). This questionnaire extracts scores of the task-oriented goal and the ego-oriented goal by giving seven questions and six questions, respectively. Each question was answered by a 5-point Likert scale, from 1 (I disagree completely) to 5 (I agree completely). Benar and Loghmani (2012b), quoting from Castillo, Tom'as, Balaguer, Fonseca, Dias \& Duda, (2010) confirmed the reliability and validity of this questionnaire by studying the task and ego-orientation in sport questionnaire on high school students in Spain [n (2473)] and Portugal [n (2486)] (21, 23). This questionnaire was confirmatory factorial analyzed using its Italian version by Bortoli and Robazza (2005) (24). Previous researches reviewed the reliability of each sub-scale of the questionnaire $(23,24)$. These researches reported Cronbach's Alpha coefficient of the task-orientation sub-scale between 0.62 to 0.85 and the ego-orientation sub-scale from .80 to $.85(25,26)$. In this research, the reliability of the task and egoorientation sub-scale was obtained by Cronbach's Alpha coefficient 0.80 and 0.79 , respectively. 
Statistical Analysis. The descriptive statistics methods, Spearman's correlation coefficient, Exploratory Factor Analysis (EFA) with a varimax rotation by software of SPSS, and Confirmatory Factor Analysis (CFA) were used to analyze the data via LISREL software. By using the descriptive statistics methods, data was obtained including the average and standard deviation of the research variables scores.

\section{RESULTS}

The reliability of the measurements was evaluated using Cronbach's Alpha the scores. The reliability scores of all the constructs are considered adequate (Table 1 and 2). In present study, actual results calculated through three methods. First, divergent validity of constructs were obtained from exploratory factor analysis, and then convergent and discriminant validities of research constructs were achieved by confirmatory factor analysis.

Exploratory Factor Analysis (CFA). EFA was conducted to test the divergent validity of PMQ and TEOSQ. Principal axis factoring was chosen over other methods of extraction because it is mostly used and understood (26). More importantly, principal axis factoring extraction method analyzed the common or shared variance among items while unique and error variance were eliminated (27-30). The factor structure of the PMQ has been variable in prior research studies and so a factor analysis with varimax rotation was performed on the data. Items and factors were selected by the criteria of factor loadings above 0.50. A five-factor solution was revealed explaining $50.3 \%$ of the variance (Table 1). The five-factor solution (e. g., fitness, skill development, team atmosphere, status, and energy release) was also supported by the screed test. The factor solution which emerged was contrast to previous research results (10). Thirteen items were dropped from subsequent analyses due to cross-loadings and loading lower than 0.50 .

Table 1. Factor structure of PMQ

\begin{tabular}{|c|c|c|c|c|c|}
\hline $\begin{array}{c}\text { Items } \\
\text { [Stem: I participate in sport because...] }\end{array}$ & Fitness & $\begin{array}{c}\text { Skill } \\
\text { Development }\end{array}$ & $\begin{array}{c}\text { Team } \\
\text { Atmosphere }\end{array}$ & Status & $\begin{array}{l}\text { Energy } \\
\text { Release }\end{array}$ \\
\hline 2. I want to stay in shape & .82 & & & & \\
\hline 3. I want to be physically fit & .87 & & & & \\
\hline 4. I want to improve my skills & & .60 & & & \\
\hline 12. I want to learn new skills & & .67 & & & \\
\hline 5. I like the team spirit & & & .68 & & \\
\hline 6. I like to against too difficult & & & .55 & & \\
\hline 7. I like to do practice & & & .67 & & \\
\hline 8. I like being on a team & & & .64 & & \\
\hline 11. I like the teamwork & & & .76 & & \\
\hline 9. I like to compete & & & & .61 & \\
\hline 17. I like to win & & & & .72 & \\
\hline 19. I like to feel important & & & & .64 & \\
\hline 21. I want to be popular & & & & .59 & \\
\hline 20. I want to release energy & & & & & .64 \\
\hline 22. I want to get rid of energy & & & & & .50 \\
\hline 23. I like to get out of the house & & & & & .69 \\
\hline 25. I like to travel & & & & & .57 \\
\hline Cronbach's Alpha & .83 & .25 & .76 & .70 & .70 \\
\hline
\end{tabular}

Benar, N., and Loghmani, M. (2014). Ann Appl Sport Sci, 2(1): 69-80. 
In contrast of PMQ, the factor solution of TEOSQ which emerged was similar to previous research results $(20,31)$. One item, 5 (I learn something that is fun to do) crossloaded and were dropped from subsequent analyses. A two-factor solution was revealed explaining $49.9 \%$ of the variance. The twofactor solution was also supported by the screed test. According to table 2, factors of task orientation (six items) and ego orientation (six items) were identified.

Table 2. Factor structure of TEOSQ

\begin{tabular}{lcc}
\hline Items & $\begin{array}{c}\text { Ego } \\
\text { Orientation }\end{array}$ & $\begin{array}{c}\text { Task } \\
\text { Orientation }\end{array}$ \\
\hline 1. I'm the only one who can do the play or skill & .63 & .74 \\
3. I can do better than my friends & .76 & .64 \\
4. The other can't do as well as me & .60 & .66 \\
6. Others mess up and I don't & .74 & .75 \\
9. I score the most points & & .67 \\
11. I am the best & & .69 \\
2. I learn a new skill and it makes me want to practice more & .74 \\
7. I learn a new skill by trying hard & & .80 \\
8. I work really hard & & $\mathbf{. 8 2}$ \\
10. Something I learn makes me want to practice more & \\
12. A skill I learn really feels right & .79 \\
13. I do my very best & & \\
Cronbach's Alpha & & \\
\hline
\end{tabular}

Spearman's correlation coefficients of all constructs have been showed in Table 3 . Generally based on these results, negative and significantly correlation have been seen between sport participation motives and goal orientations.

Table 3. Correlations of all constructs

\begin{tabular}{lcccccc}
\hline \multicolumn{1}{c}{ Constructs } & $\begin{array}{c}\text { Skill } \\
\text { Development }\end{array}$ & $\begin{array}{c}\text { Team } \\
\text { Atmosphere }\end{array}$ & Status & $\begin{array}{c}\text { Energy } \\
\text { Release }\end{array}$ & $\begin{array}{c}\text { Ego } \\
\text { Orientation }\end{array}$ & $\begin{array}{c}\text { Task } \\
\text { Orientation }\end{array}$ \\
\hline Fitness & $.20^{* *}$ & $.24 * *$ & $.30^{* *}$ & $.30^{* *}$ & $-.11^{*}$ & $-.15^{* *}$ \\
Skill Development & & $.38^{* *}$ & $.19 * *$ & $.16^{* *}$ & .04 & $-.28^{* *}$ \\
Team Atmosphere & & $.33^{* *}$ & $.31 * *$ & .01 & $-.34^{* *}$ \\
Status & & & $.51^{* *}$ & $-.36^{* *}$ & $-.14^{* *}$ \\
Energy Release & & & & $-.18^{* *}$ & $-.12^{*}$ \\
Ego Orientation & & & & & $.19^{* *}$ \\
\hline
\end{tabular}

Confirmatory Factor Analysis (CFA). The Structural Equation Models (SEMs) for the five domains underlying the PMQ and two dimensions underlying the TEOSQ for the athletes (first-order measurement model), respectively are given in Figures 1 and 2 .
The latent variables have been allowed to correlate with one another. The first-order CFA results for SEM of PMQ (RMSEA = .050; chi-square $=212.58 ; d f=109 ; P=$ $.001)$ and TEOSQ (RMSEA $=.057$; chisquare $=118.54 ; d f=53 ; P=.001)$ showed 
that these models had been fitted. Steiger (1995) has demonstrated RMSEA values (badness index) less than 0.10 as an acceptable model fit (32). The chisquare/degrees of freedom ratio for PMQ are
1.95, and for TEOSQ are 2.23. Vorster et a.l (2005), quoting from Carmines and McIver (1981, p 800), state that the relative chisquare (badness index) should be in the $2: 1$ to 3:1 range for an acceptable model (33).
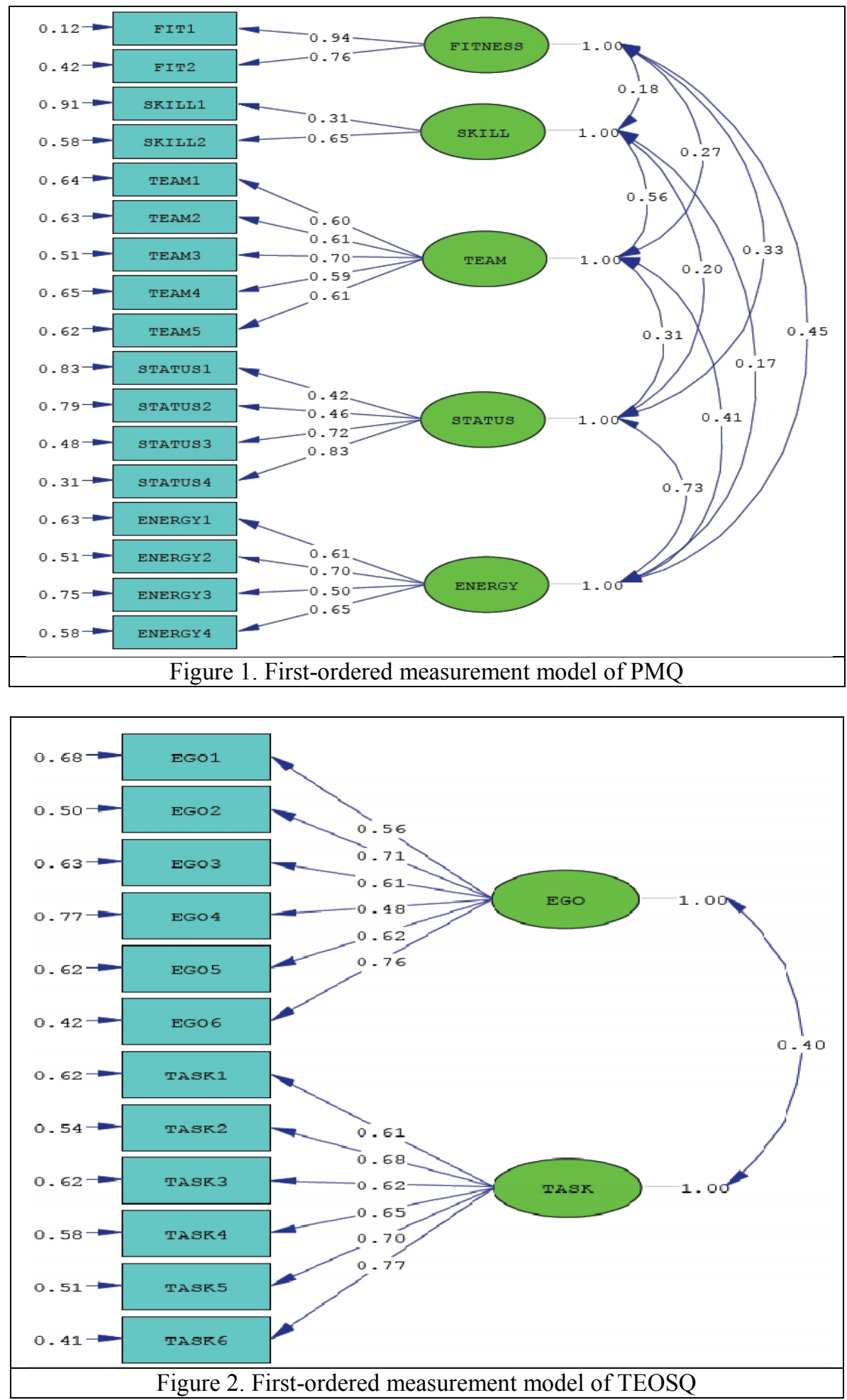

Benar, N., and Loghmani, M. (2014). Ann Appl Sport Sci, 2(1): 69-80. 
The second-ordered measurement model also demonstrated good fit with RMSEA = .056 ; chi-square $=248.79 ; \mathrm{df}=114 ; \mathrm{P}=.001$; $\mathrm{CFI}=.94 ; \mathrm{IFI}=.91 ; \mathrm{NFI}=.93$ for $\mathrm{PMQ}$ (Figure 3 ), and RMSEA $=.058$; chi-square $=$ $118.54 ; \mathrm{df}=52 ; \mathrm{P}=.001 ; \mathrm{CFI}=.92 ; \mathrm{IFI}=.94$; $\mathrm{NFI}=.95$ for TEOSQ (Figure 4). A value of 0.90 (goodness indexes) is considered to be a good fit for all the above fit indices (34). The standardized factor loadings of PMQ ranged from .26 to .94 , and the standardized factor loadings of TEOSQ ranged from .48 to .93 at significant level of $\mathrm{P} \leq .05$. These indexes show support for the convergent and discriminant validities of models. As indicated in figure 3 , the factor loadings results showed that motives of energy release (.94), status (.76), fitness (.48), team atmosphere (.46), and skill development (.26) were identified respectively, also according to figure 4, based on secondordered measurement model teenage athletes participate in sports settings with goals of task orientation (.93) and ego orientation (.43), respectively.

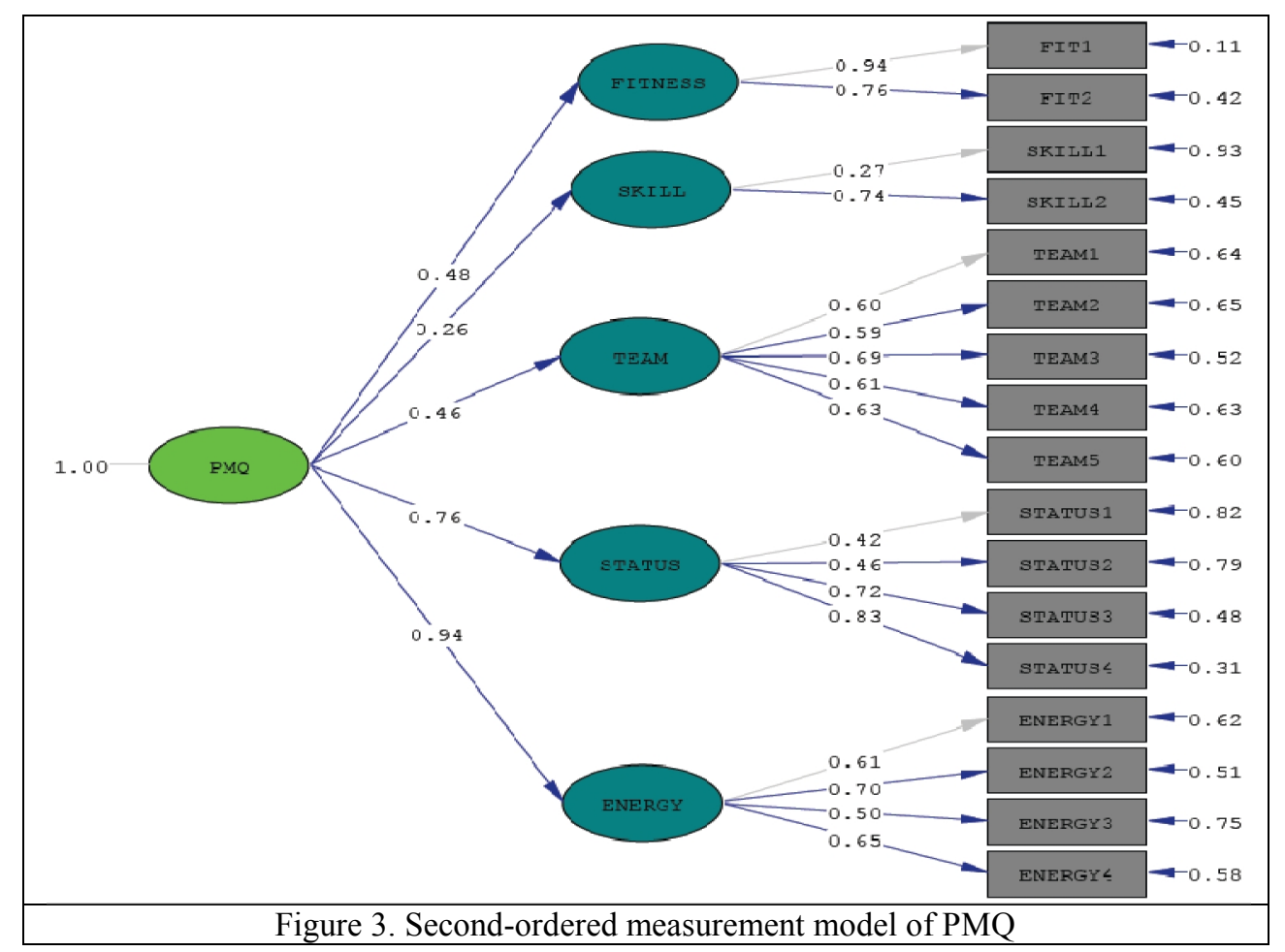

\section{DISCUSSION}

The purpose of the present study was the factor analysis of achievement goals and sports participation motives among teenage athletes. According to the researches, motivation is an essential element that plays an important role in making physical behavior and sport in youths $(9,35)$.

This study showed that teenage athletes mainly participated in physical activities with five core motives of skill development, energy release, team atmosphere, status, and fitness. Based on research, it can be consequent that teenagers mainly have external motives for sports participation in leisure times, because motives of energy release and status obtained first and second priorities sports participation motives. These findings are in contrast to studies of Zahariadis \& Biddle (2000), Gill et al. 
(1983), because most researches indentified six main motives $(20,34)$. For example, Gill et al (1983) and Zahariadis and Biddle (2000) have determined six motives of skill development, energy release, team atmosphere, status, fitness, and affiliation $(20,34)$. It seems that Iranian teenagers, rather than European teenagers, had a lower motive for sports participation, as motive of affiliation doesn't appear for Iranian teenagers, while this motive is one of most important sports participation motives for English teenagers (10). Of course, Zahariadis and Biddle (2000) examined sports participation motivation of teenagers (11-16 years old) for physical education classes in school, whereas the present study investigated sports participation motivation of teenagers in leisure times (out of school times) (34). This finding shows its possible motives of sport participation among teenagers different in variety of environments. In fact, environmental varieties can be playing an important role in form of sports participation motives among teenagers. By these explanations, environmental variety included an important antecedent of sports participation motivation, and can be expected that educational settings and school class's times had varieties more than out of school and leisure times (sport settings). Thus, probably teenagers who participate in physical education class's times (educational settings) have more internal motives than teenagers who participate in leisure and out of school times (sport settings), because of this study, highest priorities for sports participation motivation of active teenagers in sports settings (e. g., leisure and out of school times) included external motives of energy release and status.

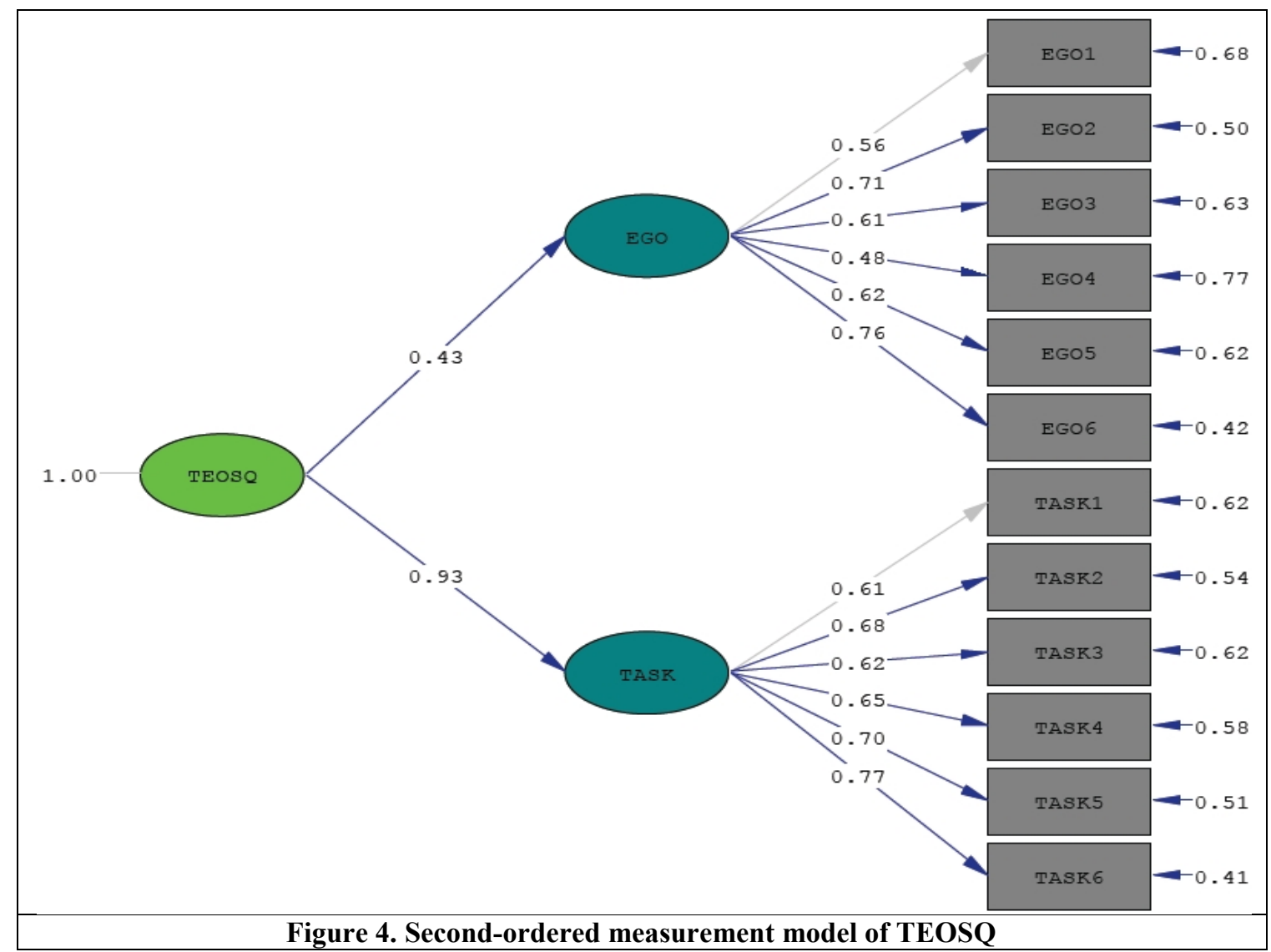

Benar, N., and Loghmani, M. (2014). Ann Appl Sport Sci, 2(1): 69-80. 
Based on CFA results, further validity for the constructs of task and ego goal orientations has been demonstrated that they supported previous researches $(10,24,35-$ 38). The present study, in the field of importance of achievement goals priorities, showed that task orientation has more than ego orientation among teenage athletes, but the results of Spearman's correlation coefficient indicated that there are negatively and statistically significant associations between task orientation and all motives of sport participation. In contrast, Papaionnou and McDonald (1993), Zahariadis and Biddle (2000), Alahverdiyani et al (2010), Spray et al (2008), Hodge et al (2008) showed that skill development and team atmosphere incentives were highly related to task orientation, and ego orientation was associated clearly with status incentive (10, 39-41). These empirical evidences show that there are various antecedents (e. g., type of sport, environmental situation, gender, age, local differences, etc) for sports participation motivation and achievement goal orientations among teenagers.

Given that environmental variety (e. g., competitive, leisure time, class and educational settings) influences sports participation motivation, Papaioannou et al. (2007) have demonstrated that the settings can influence individuals' achievement goal orientations (37). For this evidence, it could be expected that teenage athletes, in sports settings and sports commitment, mainly participated in sport activities with external motives and less task orientation. Based on Benar and Loghmani (2012a) there were negatively and significantly associations between task orientation and sport commitment among teenage athletes in sports settings (11), whereas teenage athletes in educational settings mainly participated in sports activities by internal motives and more task orientation $(10,20)$.

Parents like sports teachers are considered as the supportive elements of youths in instructional fields. Social supports, especially the supportive element of parents' high education level, play a vital role in increasing youths' motivation to do physical activities and making selfconfidence. The reason is that high education makes a good economic-social situation to family and according to the evidences, youths who don't have an appropriate economic-social situation, are less supported by their parents in sport participation (41).

\section{CONCLUSION}

Finally, we found that physical activity in sport and competitive environments (e. g., leisure times and out of school times) could be different from educational environments (e. g., school class's times). For this reason, in the present study it cleared teenagers who participated in sports and competitive environments, in contrast to teenagers who participated in educational environments, had more external motives (e. g., status and energy release) and less task orientation. Hence, we suggest that future studies focus directly on environmental and cultural differences in examining sports participation motivation and achieving goal orientations among teenagers. Definitely, these evidences could provide some guidelines for sports managers to set and arrange some sports programs in youths' leisure time.

\section{REFFRENCES}

1. Chin N-S, Khoo S, Low W-Y. Sex, Age Group and Locality Differences in Adolescent Athletes' Beliefs, Values and Goal Orientation in Track and Field. Journal of Exercise Science \& Fitness. 2009;7(2):112-21.

2. Costello AB, Osborne JW. Best Practices in Exploratory Factor Analysis: Four Recommendations for Getting the Most From Your Analysis. Practical Assessment Research \& Evaluation. 2005;10(7):1-9. 
3. Barnett LA. Accounting for Leisure Preferences from Within: The Relative Contributions of Gender, Race or Ethnicity, Personality, Affective Style, and Motivational Orientation2006.

4. Stephens DE. Moral atmosphere and aggression in collegiate intramural sport. International Sports Journal. 2004;8(1):65-75.

5. Wang CKJ, Koh THM. Sport Ability Beliefs, Achievement Goals, Self, Determination and Beliefs About the Purposes of Physical Education Among Singaporean Preservice Physical Education Trainees. Asian Journal of Exercise \& Sports Science. 2006;3(1):25-35.

6. Holt NL, Tamminen KA, Black DE, Sehn ZL, Wall MP. Parental involvement in competitive youth sport settings. Psychology of Sport and Exercise. 2008;9(5):663-85.

7. Keegan RJ, Harwood CG, Spray CM, Lavallee DE. A qualitative investigation exploring the motivational climate in early career sports participants: Coach, parent and peer influences on sport motivation. Psychology of Sport and Exercise. 2009;10(3):361-72.

8. Biddle S. Sport and exercise motivation: A brief review of antecedent factors and psychological outcomes of participation. In: Green K, Hardman K, editors. Physical Education: A Reader. 1st ed: Meyer \& Meyer Fachverlag und Buchhandel GmbH; 1998. p. 154-83.

9. Gershgoren L, Tenenbaum G, Gershgoren A, Eklund RC. The effect of parental feedback on young athletes' perceived motivational climate, goal involvement, goal orientation, and performance. Psychology of Sport and Exercise. 2011;12(5):481-9.

10. Wilson KS, Spink KS. Predicting parental social influences: The role of physical activity variability. Psychology of Sport and Exercise. 2012;13(1):1-9.

11. Benar N, Loghmani M. The Relationship between Goal-Orientations and Sport Commitment Among Athletes. Pedagogika, psihologia ta mediko-biologicni problemi fizicnogo vihovanna i sportu. 2012;5:154-60.

12. Cecchini JA, Méndez A, Muñiz J. Motives for practicing sport in Spanish schoolchildren. Psicothema. 2002;14(3):523-31.

13. Rees DI, Sabia JJ. Sports participation and academic performance: Evidence from the National Longitudinal Study of Adolescent Health. Economics of Education Review. 2010;29(5):751-9.

14. Yousefi M, Ramzaninezhad R, Hemmatinezhad M. The Relationship Between Team Motivational Climate and Goal Orientation in Athletes. World Journal of Sport Sciences. 2009;2(2):125-8.

15. Slutzky CB, Simpkins SD. The link between children's sport participation and self-esteem: Exploring the mediating role of sport self-concept. Psychology of Sport and Exercise. 2009;10(3):381-9.

16. Elliot AJ, Cury F, Fryer JW, Huguet P. Achievement Goals, Self-Handicapping, and Performance Attainment: A Mediational Analysis. Journal of Sport \& Exercise Psychology. 2006;28(3):344-61.

17. Lisha NE, Sussman S. Relationship of high school and college sports participation with alcohol, tobacco, and illicit drug use: A review. Addictive Behaviors. 2010;35(5):399-407.

18. Pastor Y, Balaguer I, Pons D, Garcia-Merita M. Testing direct and indirect effects of sports participation on perceived health in Spanish adolescents between 15 and 18 years of age. Journal of adolescence. 2003;26(6):71730. Epub 2003/12/03.

19. Boyd MP, Weinmann C, Yin ZN. The relationship of physical self-perceptions and goal orientations to intrinsic motivation for exercise. Journal of Sport Behavior. 2002;25(1):1-18.

20. Gill DL, Gross JB, Huddleston S. Participation motivation in youth sports. International Journal of Sport Psychology. 1983;14:1-14.

21. Benar N, Loghmani M. Comparison between sport participation motivation and goal-orientation of youth athletes: the role of parents' education level. Pedagogic, Psychology, Medical-Biological Problems of Physical Training and sports. 2012;12:168-73.

22. Duda JL, Nicholls JG. Dimensions of achievement motivation in schoolwork and sport. Journal of Educational Psychology. 1992;84(3):290-9.

23. Castillo I, Tomás I, Balaguer I, Fonseca AM, Dias C, Duda JL. The Task and Ego Orientation in Sport Questionnaire: Testing for Measurement Invariance and Latent Mean Differences in Spanish and Portuguese Adolescents. International Journal of Testing. 2010;10(1):21-32.

24. Bortoli L, Robazza C. Italian version of the task and ego orientation in sport questionnaire. Perceptual and motor skills. 2005;100(1):43-50. Epub 2005/03/19.

25. Edwardson CL, Gorely T. Parental influences on different types and intensities of physical activity in youth: A systematic review. Psychology of Sport and Exercise. 2010;11(6):522-35.

26. Moreno-Murcia JA, Sicilia A, Cervelló E, Huéscar E, Dumitru DC. The relationship between goal orientations, motivational climate and self-reported discipline in physical education. Journal of Sports Science and Medicine. 2011;10(1):119-29.

Benar, N., and Loghmani, M. (2014). Ann Appl Sport Sci, 2(1): 69-80. 
27. De Grazia S. Of Time, Work, and Leisure: Vintage Books; 1994. 559 p.

28. Hamilton K, White KM. Understanding parental physical activity: Meanings, habits, and social role influence. Psychology of Sport and Exercise. 2010;11(4):275-85.

29. Hanrahan S, Biddle S. Measurement of achievement orientations: Psychometric measures, gender, and sport differences. European Journal of Sport Science. 2002;2(5):1-12.

30. Stuntz CP, Weiss MR. Achievement goal orientations and motivational outcomes in youth sport: The role of social orientations. Psychology of Sport and Exercise. 2009;10(2):255-62.

31. Freeman TM, Anderman LH. Changes in mastery goals in urban and rural middle school students. Journal of Research in Rural Education. 2005;20(1):1-13.

32. Steiger JH. Manual to Statistica. Tulsa: SEPATH; 1995.

33. Vorster M, Olckers C, Buys MA, Schaap P. The construct equivalence of the job diagnostic survey for diverse South African cultural groups. SA Journal of Industrial Psychology. 2005;31(1):31-7.

34. Zahariadis PN, Biddle SJH. Goal orientations and participation motives in physical education and sport: Their relationships in English schoolchildren. Athletic Insight: the Online Journal of Sports Psychology. 2000;2(1):112.

35. Verkooijen KT, Nielsen GA, Kremers SPJ. Leisure time physical activity motives and smoking in adolescence. Psychology of Sport and Exercise. 2009;10(5):559-64.

36. Alahverdiyani K, Didar J, Yadegar MMM. Relationship between Achievement goal Orientation of female Track runner university students and perceived motivational climate in sprint and endurance events. Procedia - Social and Behavioral Sciences. 2010;5(0):1681-4.

37. Papaioannou AG, Milosis D, Kosmidou E, Tsigilis N. Motivational Climate and Achievement Goals at the Situational Level of Generality. Journal of Applied Sport Psychology. 2007;19(1):38-66.

38. Stevenson SJ, Lochbaum MR. Understanding exercise motivation: examining the revised social-cognitive model of achievement motivation. Journal of Sport Behavior. 2008;31(4):389-412.

39. Hodge K, Allen JB, Smellie L. Motivation in Masters sport: Achievement and social goals. Psychology of Sport and Exercise. 2008;9(2):157-76.

40. Spray CM, John Wang CK, Biddle SJH, Chatzisarantis NLD. Understanding motivation in sport: An experimental test of achievement goal and self determination theories. European Journal of Sport Science. 2006;6(1):43-51.

41. Worthington RL, Whittaker TA. Scale Development Research: A Content Analysis and Recommendations for Best Practices. The Counseling Psychologist. 2006;34(6):806-38. 


\section{تازههاى علوم كاربردى ورزش \\ موره دوم، شماره اول

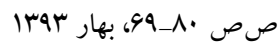 \\ تحليل عاملى هدفمدارى و انَيزه مشار كت ورزشى نوجوانان ورزشكار در اوقات فراغت ومده

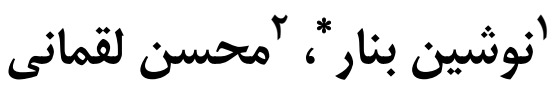

مقاله اصيل

تاريخ دريافت:

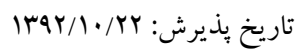

ا. استاديار گروه مديريت ورزشى، دانشكده تربيتبدنى و علوم ورزشى، دانشگاه گيلان، رشت، ايران.

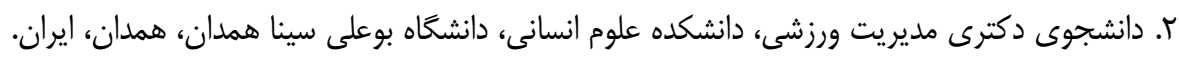

هدف از يزوهش حاضر شناسايى مهمترين اهداف و انخَيزهاى مشاركت ورزشى اوقات فراغت در نوجوانان ورزشكار بود. همجنين، اين متغيرها

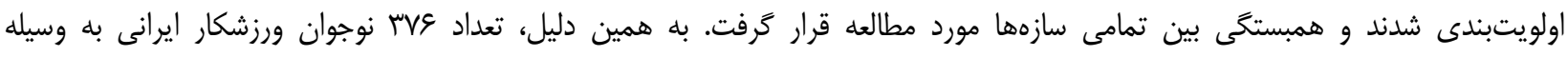

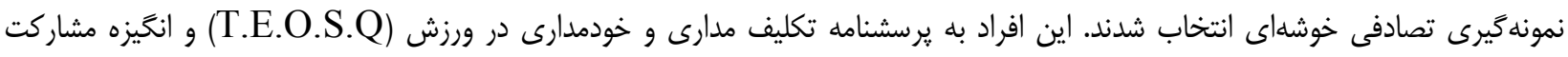

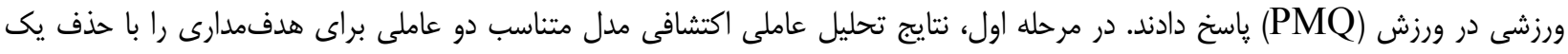

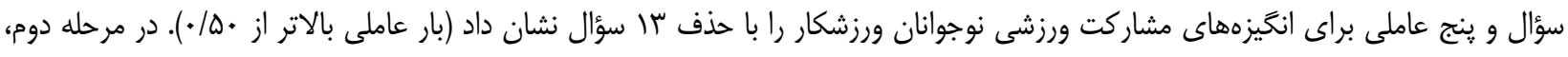

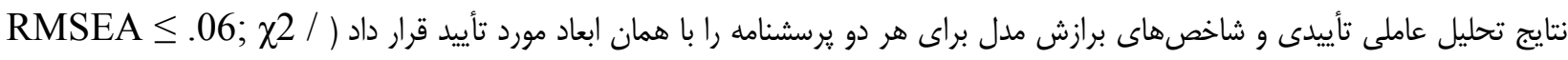
(df $\leq 3$; Goodness Indexes $\geq .90$

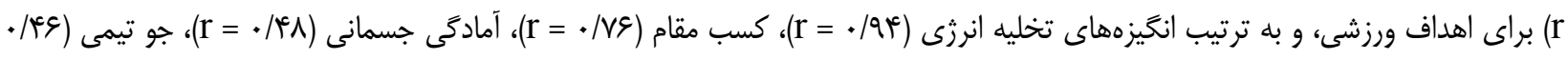

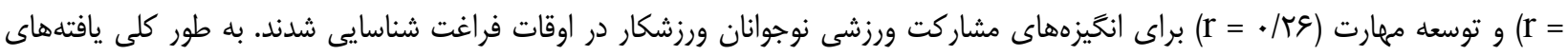

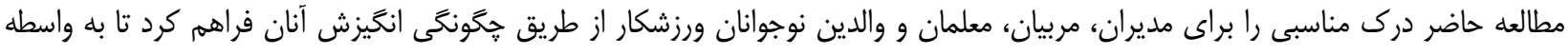

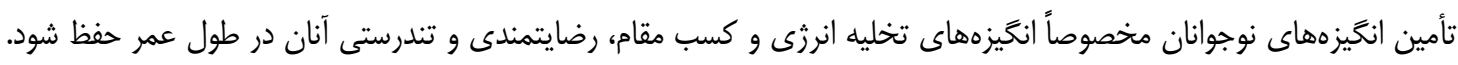

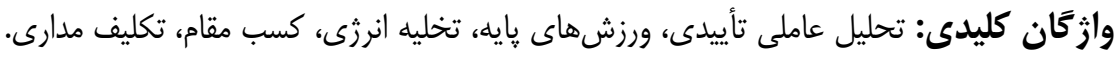

\footnotetext{
: - نوسنده مسئول: *

نوشين بنار

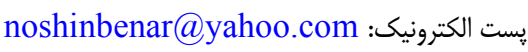

